\title{
MORPHOLOGICAL CHARACTERIZATION OF BODIES WITH CERAMIC FORMULATED VITREOUS USING WASTE OF FLUORESCENT AS FONDANT
}

\author{
A.M.B Araújo ${ }^{1 ;}$ V.S. Porto ${ }^{2}$;C.R.S. Morais²; M.S.L. Cavalcanti ${ }^{3}$ \\ ${ }^{1}$ Programa de Pós-Graduação em Engenharia de Processos-UFCG \\ ${ }^{2}$ Unidade Acadêmica de Engenharia de Materiais - CCT - UFCG \\ ${ }^{3}$ Departamento de Ciências Básicas e Sociais- CCHSA-UFPB \\ "Corresponding author's email: angelmba2012@hotmail.com
}

\begin{abstract}
This work seeks to contribute to the technological alternatives for the reuse and recycling of glass, which can offer a number of advantages for the environment, and reducing the costs of collection and manufacture of the product, using the glassy residue of fluorescent lamp as a flux in production of white ceramic. The disposal of fluorescent lamps cause irreparable harm both humans and the environment. Therefore, it becomes of paramount importance to this study. The research characterizing porcelains formulated without waste glass and waste glass partially replacing feldspar in the proportions of $5 \%$, $10 \%, 15 \%$ and $20 \%$ were then molded specimens was performed at $1000{ }^{\circ} \mathrm{C}$ and burned, $1100^{\circ} \mathrm{C}, 1150^{\circ} \mathrm{C}, 1200{ }^{\circ} \mathrm{C}$ and $1250^{\circ} \mathrm{C}$. These specimens, physical and mechanical tests were performed, such as: X-Ray Diffraction; morphological characterization and flexural of ceramic bodies. The results indicated the feasibility of using this waste in partial replacement of feldspar before his potential as a flux for this type of application since, in general all the samples showed results within the recommended specifications for the ceramic industry white.
\end{abstract}

Keywords: glassy waste, white ceramic, physical and mechanical tests, scanning electron microscopy.

\section{INTRODUCTION}

Considering that Brazil sells about 100 million lamps per year and knowing also that the industries of recycling mercury lamps are responsible for the control of only about $6 \%$ of the stock of lamps burned in the country, the problem of disposal of these wastes escalates dramatically ${ }^{(1)}$.

The reuse of glassy waste, and reduce environmental impact, can contribute to the diversification of manufacturing products and to reduce the final cost of production, since it can act as a flux ${ }^{(2)}$.

The company Lepri Rustic Fine Ceramics, Glass recycles fluorescent lamps to produce floors and ceramic tiles, where $99 \%$ of its products contain $25 \%$ of this material in their droves, generating $15 \%$ of energy savings in the firing process and facilitating the drying of ceramic products ${ }^{(3)}$.

This study aimed to seek alternative technologies to reuse glassy waste fluorescent lamps in white ceramic manufacturing.

\section{MATERIALS AND METHODS}

The following traditional raw materials were used in this work: clay, derived from Alhambra / PB; quartz, feldspar and kaolin, from the Reed Seridó/PB, donated by the company COTEBRAS (Tecnocerâmica Company of Brazil). Waste glass of fluorescent lamps were donated by an industry of Ceará, has benefited. All raw materials were characterized for preparation of triaxial masses using the inorganic dispersant (Sodium Silicate), lent by Luzarte the state of Pernambuco. To determine the phases present, we used an X-ray diffractometer at the Laboratory of Materials Characterization UFCG.

The composition of the mass standard for sanitary stoneware followed the recommendation of Santos (1992) (4), and the program also applied to reformulate porcelains, called REFORMIX 2.0. Masses benchmark with and without glass waste fluorescent lamps partially replacing feldspar in the proportions of 5\%,10\%, 15\% and 20\% in an attempt to find a suitable percentage of waste that do not compromise the recommended properties for manufacturing were formulated white ceramic.

For bonding of the slips plaster molds have been used by applying a thin layer of talc to facilitate undercut, immediately after the slurry was poured into natural drying. Subsequently bodies were removed from the molds and placed in an oven at $110^{\circ} \mathrm{C}$ for 24 hours.

The specimens were burned in muffle oven EDG / FC Series 1.25. Academic Unit of the Laboratory of Materials Engineering UFCG. The firing temperatures used were $1000^{\circ} \mathrm{C}, 1100^{\circ} \mathrm{C}, 1150^{\circ} \mathrm{C}, 1200^{\circ} \mathrm{C}$ and $1250^{\circ} \mathrm{C}$ with heating rate of $5^{\circ} \mathrm{C} / \mathrm{min}$ and $120 \mathrm{~min}$ time the level of burning. The physical test was conducted with the purpose of evaluating the color of the specimen after drying and firing. The mechanical testing was performed using the flexural Modulus of Rupture (MRF), which determine the value of the load applied to the specimen after the uniformly cause breakage of this increased load. An analyzer flexural strength was used to three points Shimadzu / Autograph AG brand - X 50KN.

For the test of scanning electron microscopy, the ceramic body was metallized with gold ("sputtering" - sputter Shimadzu - 
IC-50, using a current of $4 \mathrm{~mA}$, for a period of 2 minutes) then for the test to be performed on a scanning electron microscopy of Shimadzu, model SSX-500.

\section{RESULTS AND DISCUSSION}

Figure 1 shows the XRD patterns of the raw materials studied, which confirms the presence of clay minerals and high kaolinite content proving favoring the use of these substances are shown in white ceramic.

Figure 1 - diffractograms of raw materials: kaolin, glass lamp, quartz, feldspar and clay

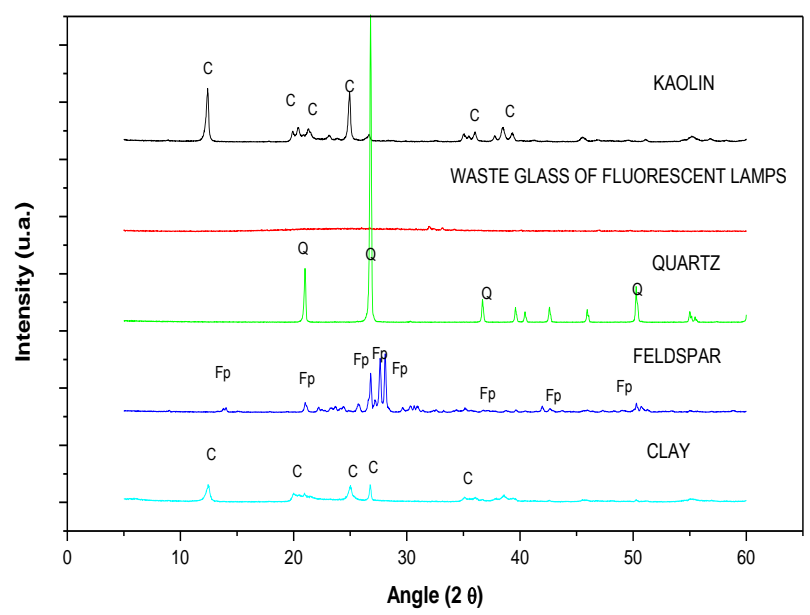

In Figure 2 the values of tension strength of specimens with $0 \%, 5 \%, 10 \%, 15 \%$ and $20 \%$ glassy residue, depending on the firing temperatures are presented.

Figure 2 - Maximum voltage as a function of the firing temperature of the specimens with $0 \%, 5 \%, 10 \%, 15 \%$ and $20 \%$ glassy residue

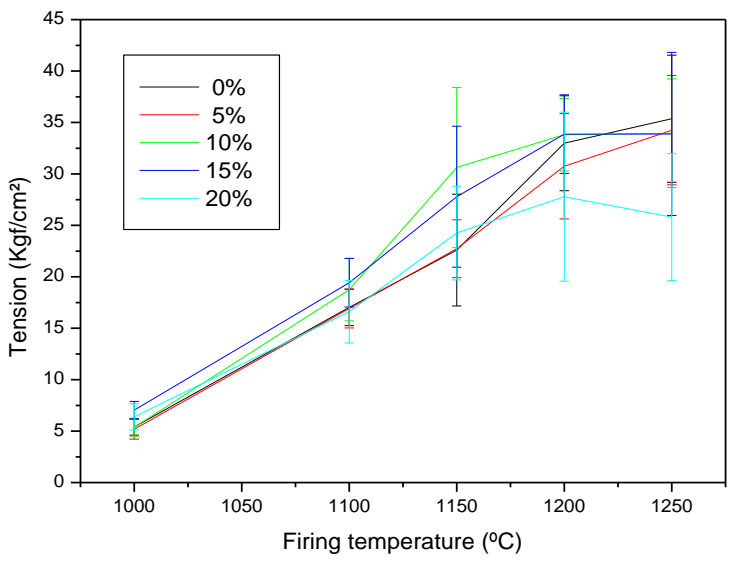

All the samples showed values of Breakdown Voltage above $27 \mathrm{~N} / \mathrm{mm}{ }^{(5)}$, which is allowed by European Standard EM 100 , the firing temperature of $1200^{\circ}$. Pasta with $5 \%, 10 \%$ and $15 \%$ of waste glass in replacement of feldspar and reached approximately the mass of the standard temperature $1250^{\circ} \mathrm{C}$.

It is found that the mass with $10 \%$ and $15 \%$ glass had values above the standard already in the firing temperature $1150^{\circ} \mathrm{C}$ reaching maximum values of voltage at $1200^{\circ} \mathrm{C}$, remaining almost stable until $1250^{\circ} \mathrm{C}$. The volume with $20 \%$ residue and reached its maximum value within the allowed level of the burning of $1200^{\circ} \mathrm{C}$, with a value slightly below the standard in $1250^{\circ} \mathrm{C}$, which must be taken into account occurrences in other properties such as small increase in porosity this firing temperature. Hence we see the importance for a final assessment in considering together the results of physical and mechanical properties, whereas the second Inmetro's different levels of degree of water absorption directly affect the characteristics of ceramics in that its mechanical strength is directly related this property: the lower the water uptake, the greater its resistance ${ }^{(6)}$.

Table 1 presents the results of the variation in color of the ceramic bodies in the formulations studied after firing at

\begin{tabular}{l|ccccc}
\hline \multicolumn{5}{c}{ Color variation of the specimens of compositions formulated in firing } \\
temperatures \\
\hline FIRING & STANDARD & $5 \%$ & $10 \%$ & $15 \%$ & $20 \%$ \\
\hline $1150^{\circ} \mathrm{C}$ & & & & & \\
$1200{ }^{\circ} \mathrm{C}$
\end{tabular}

temperatures of $1150^{\circ} \mathrm{C}, 1200^{\circ} \mathrm{C}$ and $1250^{\circ} \mathrm{C}$. Occurs through this test that all specimens obtained coloration in shades of clear industry standards cited by Neves $(2002)^{(7)}$, can be used for the manufacture of white ceramic. These results corroborate those obtained by Cavalcanti (2012) ${ }^{(8)}$ and are confirmed by the low levels of coloring oxides presented in the chemical analysis. It can also be noted that the tone of the ceramic bodies has a higher bleaching and brightness grows to the extent that the incorporation of glassy residue replacing the feldspar for all firing temperatures.

Table 1 Changes in color after firing of ceramic bodies studied

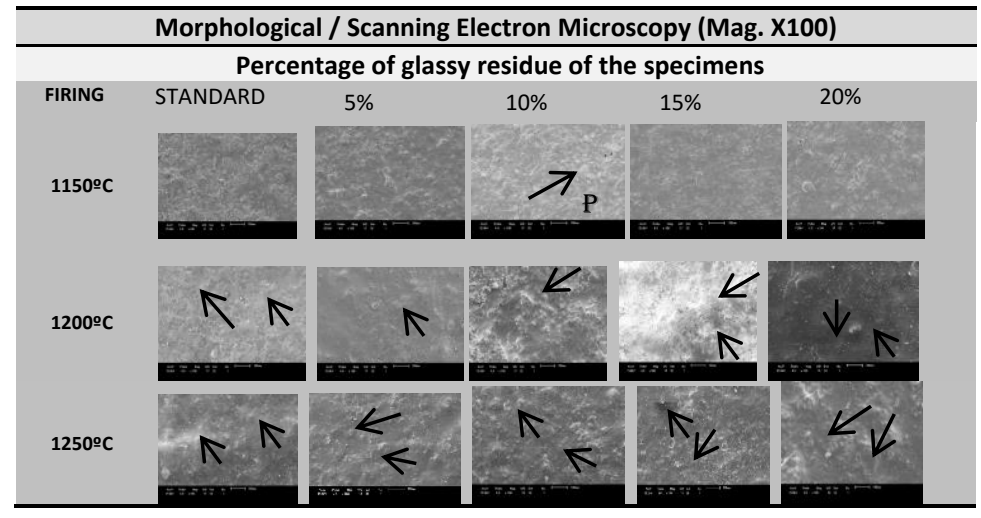


Tables 2 and 3 show the micrographs of the surface of ceramic bodies without glassy residue and 5\%,10\%, 15\% and $20 \%$ glassy residue replacing feldspar obtained in $1150^{\circ} \mathrm{C}$ burning temperature, $1200^{\circ} \mathrm{C}$ and $1250^{\circ} \mathrm{C}$ with magnification 100 and 5000 times, respectively, without chemical etching aiming at observing the porosity of the samples.

Table 2 micrographs of the ceramic bodies with and without $5 \%, 10 \%, 15 \%$ and $20 \%$ glassy residue, at temperatures of burning $1150^{\circ} \mathrm{C}, 1250^{\circ} \mathrm{C}$ and $1200^{\circ} \mathrm{C}$, with magnification of 100 times.

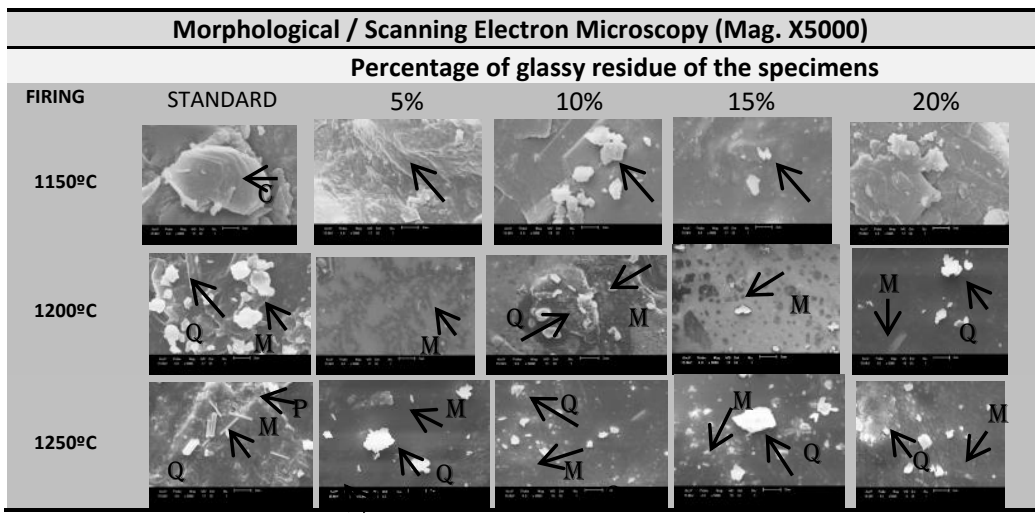

It can be seen from Table 3 and $1150^{\circ} \mathrm{C}$ at temperatures of $1200^{\circ} \mathrm{C}$ for all formulations exhibit characteristic forms agglomerates and kaolinite, mullite and quartz. Also observed in the temperature $1250^{\circ} \mathrm{C}$ that all ceramic forming liquid phase bodies.

Table 3 micrographs of the ceramic bodies without and with $5 \%, 10 \%, 15 \%$ and $20 \%$ glassy residue at temperatures of burning $1150^{\circ} \mathrm{C}, 1250^{\circ} \mathrm{C}$ and $1200^{\circ} \mathrm{C}$, with 5000 times magnification.

\section{CONCLUSIONS}

The specimens with $10 \%$ and $15 \%$ of glassy residue reached stability threshold temperature lower than $1250^{\circ} \mathrm{C}$ in mechanical property determined.

- All specimens showed less than $10 \%$ linear shrinkage, and maximum allowed burst above the firing temperature of $1200^{\circ} \mathrm{C}$, being within recommended by industry specifications for sanitary stoneware tension.

From the evaluation results presented indicate the feasibility of using the special glass residue in partial replacement of feldspar on its potential as a flux for this type of application.

\section{REFERENCES}

[1] JÚNIOR W. A. D. e WINDMÖLLER C. C., A questão do mercúrio em lâmpadas fluorescentes, Recebido em 26/7/06, aceito em 7/3/08, Disponível em 〈http://qnesc.sbq.org.br〉 . Acesso em 20 de novembro de 2011.

[2] RECICLOTECA - Centro de Informações sobre Reciclagem e Meio Ambiente. Conheça sua Embalagem de vidro. Informativo Recicloteca n³,p.6,1997.

[3] CERÂMICA REAPROVEITA VIDROS DE LÂMPADAS FLUORESCENTES, TELAS DE TV E MONITORES DE COMPUTADOR Disponível em

<http://www.jornaldaregiaosudeste.com.br/noticias/ceramicareaproveita-vidros-de-lampadas-fluorescentes--telas-de-tv-emonitores-de-computador> Acesso em: 21 mar. 2014.

[4] SANTOS, P. S. Ciência e Tecnologiade Argilas.vol 2. São PauloEdgard Blucher Ltda, 1992.

[5] PORTO, V.S. Otimização no processo de incorporação de resíduo vítreo em massas cerâmicas para grés sanitário. Dissertação, 2012. Programa de Pós-Graduação em ciência e Engenharia de Materiais. Universidade Federal de Campina Grande.

[6] INMETRO. Revestimentos Cerâmicos (pisos e azulejos) Disponível em

< http://www.inmetro.gov.br/consumidor/produtos/revestimentos .asp> Acesso em 19 mar. 2014.

[7] NEVES, G. A. Reciclagem de resíduos da serragem de granitos para uso como matéria-prima cerâmica. 2002. 242p. Tese (Doutorado). Programa de Pós-Graduação em Engenharia de Processos, Universidade Federal de Campina Grande. Campina Grande/PB.

[8] CAVALCANTI, M.S.L.; PORTO, V.S.; SILVA, M. F.; CRUZ, T. B.; SILVA, C.R. Obtenção e avaliação das propriedades físicomecânica de massas cerâmicas para grés sanitários utilizando resíduo de vidro plano em sua composição. Revista Eletrônica de Materiais e Processos, v.7.1 (2012) $13-19$. 